\title{
MANAJEMEN PENGELOLAAN KELAS DI KELOMPOK A TK BINTANG KECIL SUKOHARJO KABUPATEN PATI
}

\author{
Sumiyati \\ Institut Pesantren Mathali'ul Falah Pati \\ Email: atikpaudi@gmail.com \\ Sutri Wijayanti \\ Institut Pesantren Mathali'ul Falah Pati \\ Email: wijayantisutri03@gmail.com
}

Article received: 09 Desember 2019, Review process: 05 Februari 2020

Article published: 30 Maret 2020

\begin{abstract}
This study discusses classroom management. This research is motivated by the magnitude of the influence of the condition of the room or classroom to obtain good quality of learning. This study aims to determine the classroom management, supporting factors and inhibitors in kindergarten. This type of research is descriptive qualitative research. The research instrument is the human instrument (the researchers themselves). Data collection methods used are interviews, observation, and documentation. To analyze the research data, descriptive methods are used. The results showed that the management of class management in Group A TK Bintang Kecil Sukoharjo Margorejo Pati Regency consisted of planning, organizing, implementing, and controlling. The planning includes covering the preparation of Prota, Prosem, RPPM, RPPH, and class administration preparation. Organizing is carried out by the principal, namely the principal distributing tasks to the teacher by giving direction, then giving authority or responsibility to all teachers to manage the class well so that learning objectives are maximally achieved. The supporting factors of classroom management are (1) Teachers have a high spirit of solidarity and supportive knowledge, (2) adequate facilities and infrastructure, (3) Cooperation between parents and schools is well established. While the inhibiting factor is coordination that has not gone well.
\end{abstract}

Keywords : Management, Classroom Management, Kindergarten.

\begin{abstract}
Abstrak
Penelitian ini membahas manajemen pengelolaan kelas. Penelitian ini dilatar belakangi oleh besarnya pengaruh kondisi ruangan atau kelas untuk memperoleh kualitas pembelajaran yang
\end{abstract}


baik. Penelitian ini bertujuan untuk mengetahui manajemen pengelolaan kelas, faktor pendukung dan penghambat di TK. Jenis penelitian ini adalah penelitian kualitatif deskriptif. Instrumen penelitiannya human instrument (peneliti sendiri). Metode pengumpulan data yang digunakan yaitu wawancara, observasi, dan dokumentasi. Untuk menganalisis data hasil penelitian, digunakan metode deskriptif. Hasil penelitian menunjukkan bahwa manajemen pengelolaan kelas di Kelompok A TK Bintang Kecil Sukoharjo Margorejo Kabupaten Pati terdiri dari perencanaan, pengorganisasian, pelaksanaan, dan pengawasan. Perencanaan dilaksanakan meliputi meliputi persiapan Prota, Prosem, RPPM, RPPH, dan persiapan administrasi kelas. Pengorganisasian dilakukan oleh Kepala sekolah yaitu Kepala sekolah membagikan tugas kepada guru dengan cara memberikan pengarahan, kemudian memberi wewenang atau tanggung jawab kepada semua guru untuk mengelola kelas dengan baik sehingga tujuan pembelajaran tercapai secara maksimal. Faktor pendukung manajemen pengelolaan kelas adalah (1) Guru memiliki jiwa solidaritas yang tinggi dan pengetahuan yang mendukung, (2) Sarana dan prasarana atau fasilitas yang memadai, (3) Kerjasama antara wali murid dan sekolah terjalin dengan baik. Sedangkan faktor penghambatnya adalah koordinasi yang belum berjalan dengan baik.

Kata Kunci : Manajemen, Pengelolaan Kelas, TK

\section{PENDAHULUAN}

Manajemen merupakan hal penting yang harus ada di dalam pendidikan. Hal ini menandai bahwa pendidikan tersebut telah dilaksanakan dengan baik. Sebagaimana hasil penelitan yang dilakukan oleh Alfian Erwinsyah bahwa manajemen kelas dapat membantu meningkatkan efektifitas proses belajar mengajar yang dilakukan di kelas. Penelitian ini menyatakan bahwa manajemen kelas yang baik dimulai dari penyiapan administratif, penggunaan media dan metode pembelajaran yang bervariasi dan dan menggunakan pendekatan pluralistik (Alfian Erwinsyah: 2017, 87). Manajemen pendidikan merupakan hal yang tidak dapat dipisahkan dari peradaban umat manusia. Pendidikan membentuk manusia menjadi memiliki tatanan dalam kehidupan. Berbicara mengenai pendidikan tidak hanya dimulai saat anak memasuki Sekolah Dasar (SD), akan tetapi dapat dimulai sejak usia dini. Melalui pendidikan seseorang akan belajar tentang segala pengetahuan.

Pendidikan yang diberikan kepada anak sejak dini, akan memaksimalkan pertumbuhan dan perkembangan anak. Usia anak-anak merupakan usia di mana anak mengalami perkembangan yang sangat pesat, banyak yang menyebut di usia kanak-kanak dengan istilah masa emas. Pada masa emas inilah kemampuan otak anak untuk menerima 
stimulasi pendidikan sangat baik. Orang tua perlu memberikan stimulasi pendidikan anak sedini mungkin baik melalui pendidikan dalam keluarga maupun melalui lembaga-lembaga yang menyediakan layanan Pendidikan Anak Usia Dini (PAUD) yang dewasa ini banyak berkembang di masyarakat.

Banyaknya lembaga PAUD yang tersedia di masyarakat memberikan kesempatan kepada orang tua untuk memilih layanan yang sesui dengan harapan masing-masing orang tua, karena setiap lembaga memiliki keunggulan dan tawaran layanan terbaik masing-masing. layanan pendidikan yang dipersiapkan dengan baik akan berpengaruh terhadap kualitas pembelajaran yang diselenggarakan. Termasuk bagaimana mengelola sarana prasarana yang salah satunya adalah pengelolaan kelas sebagai sumber belajar anak. Kelas yang dekelola dengan baik, akan menjadi indah, dan menjadikan peserta didik nyaman berlama-lama bermain dan belajar di kelas.

Untuk dapat membuat suatu kelas menjadi lebih optimal dalam penggunaannya, membutuhkan adanya manajemen atau pengelolaan yang baik. Pengelolaan kelas dapat di atur semenarik mungkin sehingga dapat menciptakan suasana yang nyaman sehingga memungkinkan terwujudnya kegiatan belajar dan bermain bagi anak yang kondusif (Mulyadi, 2009:1). Manajemen atau pengelolaan kelas yang dilakukan dengan baik, akan membantu terjadinya proses pembelajaran yang terarah. Pengelolaan yang baik juga akan mendukung tercapainya tujuan-tujuan pembelajaran.

Penataan sarana dan prasarana di TK Bintang Kecil khususnya dalam hal penataan ruangan untuk anak usia TK kelompok A, disesuaikan dengan kegiatan yang akan dilaksanakan. Pengelompokan meja dan kursi disesuaikan dengan kebutuhan anak sehingga mereka memiliki ruang gerak yang lebih leluasa. Dinding dimanfaatkan untuk menempel sarana yang digunakan sebagai sumber belajar, serta untuk menempel hasil kegiatan anak. Penyimpanan dan peletakan alat bermain diatur sesuai dengan fungsinya sehingga dapat melatih anak untuk pembiasaan yang ingin dicapai. Serta sirkulasi udara dan cahaya matahari diatur sedemikian rupa sehingga dapat masuk ke dalam ruangan dengan baik. Dalam manajemen pengelolaan kelas di TK Bintang Kecil guru berhak mempunyai kreativitas untuk mengelola kelas sesuai dengan kurikulum. Berdasarkan gambaran latar belakang menjadi 
landasan untuk melakukan penelitan terhadap kondisi manajemen pengelolaan kelas di TK Bintang Kecil Sukoharjo Kecamatan Margorejo Kabupaten Pati.

\section{METODOLOGI}

Penelitian ini menggunakan jenis penelitian lapangan (fielld research). Peneliti mendeskripsikan tentang manajemen pengelolaan kelas di Kelompok A TK Bintang Kecil Sukoharjo Kecamatan Margorejo Kabupaten Pati. Adapun sifat dari penelitian ini adalah deskriptif-kualitatif. Pendekatan yang digunakan dalam penelitian ini adalah pendekatan kualitatif.

Sumber data dalam pengumpulan data menggunakan data primer dan data sekunder. Sumber data primer dalam hal informan penelitian adalah guru kelas, siswa, dan kepala sekolah TK Bintang Kecil Sukoharjo Kecamatan Margorejo Kabupaten Pati. Sedangkan sumber data sekunder adalah data-data terkait manajemen pengelolaan kelas, maupun data-data internal sekolah yang meliputi: profil lembaga, sejarah berdiri, dan sebagainya. Teknik pengumpulan data yang peneliti gunakan adalah observasi, wawancara, dan dokumentasi. Sedangkan teknik analisis data yang peneliti gunakan adalah pengumpulan data, reduksi data, penyajian data, penarikan kesimpulan dan verifikasi.

\section{HASIL DAN PEMBAHASAN}

\section{Manajemen Pengelolaan Kelas di TK Bintang Kecil Sukoharjo Kabupaten Pati}

Manajemen Pengelolaan Kelas di Kelompok A TK Bintang Kecil Sukoharjo Kecamatan Margorejo Kabupaten Pati meliputi empat kegiatan, yaitu perencanaan (planning), pengorganisasian (organizing), pelaksanaan (actuating), dan pengawasan (controlling). Hal tersebut sesuai dengan pendapat Maman Sutarman dan Asih dalam bukunya yang berjudul Manajemen Pendidikan Anak Usia Dini mengemukakan bahwa dasar-dasar menajerial yang harus dilakukan oleh guru itu meliputi perencanaan (planning), pengorganisasian (organizing), pelaksanaan (actuating), dan pengawasan (controlling). Dasar manajemen kelas sebenarnya merupakan dasar-dasar manajemen yang diaplikasikan di dalam kelas oleh guru untuk mendukung tujuan pembelajaran yang hendak dicapainya. Dalam pelaksanaannya dasar-dasar manajemen tersebut harus disesuaikan dengan dasar filosofis dari pendidikan 
(belajar mengajar) di dalam kelas. Adapun gambaran uraian keempat kegiatan tersebut adalah sebagai berikut:

\section{Perencanaan (planning)}

Perencanaan pada dasarnya adalah sebuah proses kegiatan yang menyiapkan secara sistematis kegiatan-kegiatan yang akan dilakukan untuk mencapai tujuan tertentu. Demikian pula halnya dalam suatu lembaga pendidikan termasuk lembaga pendidikan anak usia dini, karena TK Bintang Kecil termasuk lembaga pendidikan anak usia dini, perencanaan harus dijadikan langkah pertama yang benar-benar diperhatikan oleh guru dalam melaksanakan manajemen pengelolaan kelas. Sebab perencanaan merupakan bagian penting dari sebuah kesuksesan. Kegiatan perencanaan dalam manajemen kelas di TK Bintang Kecil Sukoharjo Margorejo Pati pada tahap perencanaan yang sudah dilaksanakan meliputi persiapan Program Tahunan (Prota), Program Semester (Prosem), Rencana Pelaksanaa Pembelajaran Mingguan (RPPM), Rencana Pelaksanaan Pembelajaran Harian (RPPH), dan persiapan administrasi kelas. Setiap seminggu sekali semua guru berkumpul untuk membahas kegiatan dalam satu minggu kedepan dan saling saling sharing supaya tidak terjadi kesamaan dalam alat peraga.

\section{Pengorganisasian (organizing)}

Kegiatan ini dilakukan setelah planning atau perencanaan, tujuan kegiatan ini adalah untuk mencapai sasaran yang spesifik atau rumusan keseluruhan aktivitas manajemen pembelajaran di kelas. Kegiatan pengorganisasian dalam manajemen kelas di TK Bintang Kecil Sukoharjo Margorejo Pati dilakukan oleh Kepala sekolah yaitu Kepala sekolah membagikan tugas kepada guru dengan cara memberikan pengarahan, kemudian memberi wewenang atau tanggung jawab kepada semua guru untuk mengelola kelas dengan baik sehingga tujuan pembelajaran tercapai secara maksimal. Sesuai dengan pendapat Hapidin, dkk yang menyatakan bahwa pengorganisasian adalah suatu proses untuk menentukan, mengelompokkan tugas, dan peraturan secara bersama untuk mencapai tujuan, menentukan orang-orang yang akan melakukan kegiatan, menetapkan wewenang yang dapat didelegasikan pada setiap individu yang akan melaksanakan kegiatan tersebut.

Mengorganisasikan dimaksudkan agar guru bisa melaksanakan pembelajaran dengan baik, serta mengkondisikan situasi kelas yang efektif bagi peserta didik di dalam kelas. Guru 
mengorganisasikan kelasnya masing-masing yang meliputi dua hal, yaitu pengaturan media pembelajaran dan pemilihan metode pembelajaran. Di TK Bintang Kecil Sukoharjo Margorejo Pati media pembelajarannya menggunakan media gambar yang diprint atau membuat sendiri, dan menggunakan APE yang sudah disediakan sesuai kebutuhan anak. Sedangkan meode pembelajaran yang digunakan adalah bercakap-cakap, bercerita, dan demonstrasi.

3. Pelaksanaan (actuating)

Pelaksanaan merupakan tahap ketiga dalam manajemen pengelolaan kelas, pelaksanaan merupakan usaha yang dilakukan supaya perencanaan dan pengorganisasian terlaksana. Pada tahap ini, pelaksanaan yang dilakukan TK Bintng Kecil meliputi dua hal yaitu pengelolaan ruang kelas (kondisi fisik) dan pengaturan peserta didik (kondisi non fisik). Sesuai dengan pendapat Novan Ardy Wiyani sasaran yang menyatakan bahhwa manajemen kelas dapat diklasifikasikan ke dalam dua macam, yaitu pengelolaan ruang kelas dan pengaturan peserta didik.

Pengelolaan ruang kelas itu meliputi pengaturan tempat duduk, pengaturan alat-alat pengajaran, penataan keindahan dan kebersihan kelas, dan ventilasi serta tata cahaya. Pengaturan tempat duduk di kelompok A TK Bintang Kecil menggunakan formasi lingkaran ketika pengajaran ditempuh dengan cara berdiskusi. Pengaturan perabot dan alat permainan disimpan di loker yang sudah disediakan. Di TK Bintang Kecil sudah disediakan lemari maupun loker atau rak untuk menyimpan barang sesuai dengan fungsinya. Penaataan keindahan dan kebersihan kelas yang dilakukan TK Bintang Kecil meliputi hiasan dinding atau pajangan kelas, penempatan lemari, loker-loker tempat perabotan dan alat permainan, rak buku, serta pemeliharaan kebersihan. Ventilasi udara dan pencahayaan yang baik serta menyehatkan bagi anak adalah ventilasi dengan adanya petukaran oksigen yang baik dan pencahayaan yang langsung dari matahari di luar ruang kelas. Di TK Bintang Kecil ventilasi dan tata cahaya sudah disesuaikan dengan ruang kelas.

Sedangkan pengaturan peserta didik pada kelompok A di TK Bintang Kecil dilakukan melalui tindakan preventif (pencegahan) dan korektif. Tindakan preventif yang dilakukan pada kelompok A di TK Bintang Kecil selain membuat aturan atau tata tertib 
bersama, guru juga melakukan beberapa tindakan dengan meningkatkan kesadaran diri sebagai guru, meningkatkan kesadaran peserta, menunjukkan sikap hangat dan terbuka, serta mengenal dan menemukan alternatif pengelolaan.

Pada tahap pelaksanaan manajemen pengelolaan kelas di TK Bintang Kecil Sukoharjo Margorejo Pati ini secara keselurhan sudah berjalan sesuai dengan perencanaan yang telah di buat.

\section{Pengawasan (controlling)}

Pengawasan merupakan tahap akhir dalam proses manajemen pengelolaan kelas supaya hasilnya efektif dan efesien. Pada tahap ini, kegiatan pengawasan dalam manajemen pengelolaan kelas pada kelompok A di TK Bintang Kecil Sukoharjo Margorejo Pati yaitu kepala sekolah selalu melakukan pengawasan terhadap kinerja guru secara langsung dalam kegiatan belajar mengajar mulai dari sentra balok, sentra main peran, sentra bahan alam dan sentra persiapan setiap satu minggu sekali, yaitu pada hari Rabu. Untuk hari lainnya hanya melakukan pengawasan melalui whatsapp

Untuk mengetahui lebih jelas faktor pendukung manajemen pengelolaan kelas di TK Bintang Kecil Sukoharjo Margorejo Kabupaten Pati, penulis akan memaparkan 3 faktor pendukung yaitu:

a. Guru

Guru merupakan salah satu hal yang dapat menunjang keberhasilan pembelajaran dengan baik. Semua guru atau Sumber Daya Manusia (SDM) di TK Bintang Kecil Sukoharjo Margorejo Kabupaten Pati memiliki kekompakan yang tinggi. Mereka saling bekerjasama, saling mendukung, saling membantu dan saling menghargai satu sama lain dalam menjalankan tugasnya, termasuk dalam menjalankan manajemen pengelolaan kelas. Karena jika dalam sebuah lembaga guru atau Sumber Daya Manusianya tidak kompak, maka tidak akan bisa menjalankan tugas dengan baik. Selain itu, pengetahuan guru juga menjadi faktor pendukung.

b. Sarana dan Prasarana

Adanya sarana dan prasarana atau fasilitas yang memadai dalam pembelajaran anak-anak juga turut mendukung keberhasilan menuju perkembangan yang lebih baik. Begitu pula dalam 
pelaksanaan manajemen pengelolaan kelas, sarana dan prasarana juga merupakan sala satu faktor yang menjadi pendukung keberhasilannya. Berdasarkan penelitan dilapangan, sarana dan prasarana di Bintang Kecil sudah memadai. Gedungnya luas, sehingga anak bisa leluasa dalam melakukan aktifitas. Adapun kelasnya terdiri dari ruang kelas yang sudah lengkap dan sudah sesuai dengan kebutuhan peserta didik. Di TK Bintang Kecil juga ada ruang makan untuk anak-anak, ruang makan untuk guru, ruang tamu, ruang guru, tempat administrasi, aula, UKS, mushola, gudang, dan dapur. Di semua kelas selalu tersedia kamar mandi dan tempat cuci tangan di dekatnya. Begitu pula dilengkapi dengan cctv untuk memantau aktivitas di sekolah serta tempat bermain indoor dan outdoor. Adupun di tempat bermain outdoor disediakan ayunan, jungkitan, serta kuda putar.

\section{c. Kerjasama Antara Wali Murid dan Sekolah}

Hubungan kerjasama antara wali murid dan sekolah sangatlah penting. Hubungan timbal balik antara wali murid dengan sekolah yang bernilai informasi tentang situasi dan kondisi setiap peserta didik akan melahirkan suatu bentuk kerjasama yang dapat meningkatkan aktivitas belajar peserta didik di sekolah maupun di rumah.

Berdasarkan observasi yang peneliti lakukan, kerjasama antara wali murid dengan sekolah memang sudah terjalin dengan baik. Bisa dilihat ketika para wali murid meluangkan waktunya bertemu guru di sekolah untuk sharing tentang perkembangan anak atau saling memberikan informasi tentang keadaan anak, atau saling memberi petunjuk antara guru dengan orangtua. Ketika ada undangan pertemuan dengan guru sekolah, para wali murid terlihat sangat antusias dalam menghadiri acara tersebut. Selain itu para wali murid merespon dengan baik ketika pihak sekolah membutuhkan bantuan. Begitu pula sebaliknya, jika wali murid yang membutuhkan bantuan guru atau sekolah juga merespon dengan baik. Orangtua dan guru adalah satu tim dalam pendidikan anak, untuk itu keduanya memang perlu menjalin hubungan dengan baik.

Faktor penghambat dalam pelaksanaan manajemen pengelolaan kelas di TK Bintang Kecil Sukoharjo Margorejo Kabupaten Pati hanya satu, yaitu dari segi koordinasi guru. Koordinasi adalah suatu usaha yang sinkron dan teratur untuk menyediakan jumlah dan waktu 
yang tepat, serta mengarahkan pelaksanaan untuk menghasilkan suatu tindakan yang seragam dan harmonis pada sasaran yang telah ditentukan. Dengan adanya koordinasi diharapkan semua pihak yang terlibat dalam proses manajerial tersebut mengetahui dan memahami apa yang seharusnya dilakukan serta dengan siapa kita bekerja sama. Namun jika koordinasi tidak berjalan dengan baik dapat menghambat proses manajerial.

Berdasarkan observasi yang peneliti lakukan, ketidaksinkronan dalam koordinasi memang kadang terjadi, sehingga dapat menghambat pelaksanaan manajemen kelas. Hal itu merupakan salah satu kekurangan guru sebagai seorang pendidik. Sesuai dengan pendapat Ahmad Fauzi yang menyatakan bahwa guru sebagai seorang pendidik, tentunya ia juga mempunyai banyak kekurangan. Kekurangan-kekurangan itu bisa menjadi penyebab terhambatnya kreativitas pada diri guru tersebut. Termasuk dalam melaksanakan manajemen pengelolaan kelas.

\section{SIMPULAN}

Manajemen pengelolaan kelas di Kelompok A TK Bintang Kecil Sukoharjo Kecamatan Margorejo Kabupaten Pati meliputi empat kegiatan, yaitu perencanaan (planning), pengorganisasian (organizing), pelaksanaan (actuating), dan pengawasan (controlling). Implementasi di lapangan adalah sebagai berikut: (a) Perencanaan dilaksanakan meliputi meliputi persiapan Prota, Prosem, RPPH, dan persiapan administrasi kelas. (b) Pengorganisasian dilakukan oleh Kepala sekolah yaitu Kepala sekolah membagikan tugas kepada guru dengan cara memberikan pengarahan, kemudian memberi wewenang atau tanggung jawab kepada semua guru untuk mengelola kelas dengan baik sehingga tujuan pembelajaran tercapai secara maksimal. Sedangkan guru kelas bertugas mengorganisasikan kelasnya masing-masing yang meliputi pengaturan media pembelajaran dan pemilihan metode pembelajaran. (c) pelaksanaan sudah sesuai dengan apa yang telah direncanakan. Adapun pelaksanaannya ada du hal yaitu: pertama, pengelolaan ruang kelas yang meliputi pengaturan tempat duduk, pengaturan alat-alat pengajaran, penataan keindahan dan kebersihan kelas, dan ventilasi serta tata cahaya. Kedua, adalah pengaturan peserta didik. (d) tahap pengawasan, kepala sekolah selalu melakukan pengawasan terhadap kinerja guru 
secara langsung dalam kegiatan belajar mengajar di semua kelas setiap satu minggu sekali. Faktor pendukung dan faktor penghambat manajemen Pengelolaan Kelas di Kelompok A TK Bintang Kecil Sukoharjo Kecamatan Margorejo Kabupaten Pati adalah sebagai beriku: (a) Faktor pendukung diantaranya adalah Guru memiliki jiwa solidaritas yang tinggi dan pengetahuan yang mendukung, Sarana dan prasarana atau fasilitas yang memadai, Kerjasama antara wali murid dan sekolah terjalin dengan baik. (b) Faktor penghambatnya adalah koordinasi yang belum berjalan dengan baik.

\section{DAFTAR PUSTAKA}

Adi, Sugeng Susilo. 2016. Classroom Management. Malang: Universitas Brawijaya Press.

Alfian Erwinsyah. 2017. Manajemen Kelas dalam Meningkatkan Efektifitas Proses Belajar Mengajar. TADBIR: Jurnal Manajemen Pendidikan Islam, Edisi Agustus, Volume 5, No. 2.

Djamarah, Syaiful Bahri dan Aswan Zain. 2006. Strategi Belajar Mengajar. Jakarta: Rineka Cipta.

Fadlillah, Muhammad. 2014. Desain Pembelajaran PAUD. Yogyakarta: Ar- Ruzz Media..

Fauzi, Ahmad. 2013. Manajemen Pembelajaran. Yogyakarta: Deepublish.

Hapidin, dkk. 2008. Manajemen Pendidikan TK. Jakarta: Universitas Terbuka.

Harsanto, Radno. 2007. Pengelolaan Kelas Yang Dinamis. Yogyakarta: Kanisius.

Johar, Rahmah dan Latifah Hanum. 2016. Strategi Belajar Mengajar. Yogyakarta: Deepublish

Kadir, Abdul. 2012. Dasar-dasar Pendidikan. Jakarta: Prenadamedia Group.

Karwati, Euis dan Donni Juni Priansa. 2014. Manajemen Kelas (Classroom Management) Guru Profesional yang Inspiratif, Kreatif, Menyenangkan, dan Berprestasi. Bandung: Alfabeta.

Kristiawan, Muhammad. Dian Safitri., dan Rena Lestari. 2017. Manajemen Pendidikan. Yogyakarta: Deepublish.

Moleong, Lexy. 2010. Metode Penelitian Kualitatif. Bandung : Remaja Rusda Karya. Hasan, Maimunah. 2009. PAUD (Pendidikan Anak Usia Dini). Yogyakarta: Diva Press.

Mulyadi. 2009. Classroom Management. Malang: UIN-Malang Press.

Nawawi, Hadari. 2007. Metode Penelitian Bidang Sosial. Yogyakarta: Gadjah Mada University Press.

.2005 .Organisasi Sekolah dan Pengelolaaan Kelas sebagai Lembaga Pendidikan, Jakarta : Haji Masagung.

Purnomo. 2005. Strategi Pengajaran. Yogyakarta: Universitas Sanata Dharma.

Rohmad, Ali. 2009. Kapita Selekta Pendidikan. Yogyakarta: Teras.

Rusdinal dan Elizar. 2005. Pengelolaan Kelas di Taman Kanak-Kanak. Jakarta : Departemen Pendidikan Nasional, Direktorat Pendidikan Tinggi. 
Sagala, Syaiful. 2009. Manajemen Strategik dalam Peningkatan Mutu Pendidikan. Bandung: Alfabeta.

Sugiarto, Eko. 2015. Menyusun Proposal Kualitatif: Skripsi dan Tesis. Yogyakarta: Suaka Media.

Sugiyono. 2015. Metode Penelitian Kuantitatif, Kualitatif, dan R\&D. Bandung: Alfabeta.

Sukmadinata, Nana Syaodih. 2005. Metode Penelitian Pendidikan. Bandung: Remaja Rosdakarya.

Sumiyati. 2014. Konsep Dasar Pendidikan Anak Usia Dini dalam Islam. Yogyakarta: Indie Book Corner.

Susanto, Ahmad. 2011. Perkembangan Anak Usia Dini: Pengantar Dalam Berbagai Aspeknya. Jakarta: Kencana.

Susanto, Happy. 2010. Panduan Lengkap Menyusun Proposal. Jakarta: Visimedia.

Sutarman, Maman dan Asih. 2016. Manajemen Penididikan Anak Usia Dini. Bandung: CV Pustaka Setia.

Suyadi. 2015. Teori Pembelajaran Anak Usia Dini. Bandung: PT Remaja Rosdakarya.

Wiyani, Novan Ardy. 2014. Manajemen Kelas: Teori dan Aplikasi Untuk Menciptakan Kelas Yang Kondusif. Jogjakarta: Ar-Ruzz Media. 